\title{
MATEMÁTICA NO ECO: ANÁLISE DE ARTIGOS ESCRITOS PELO JESUÍTA LUIZ MONTEIRO RECKZIEGEL
}

\author{
Silvio Luiz Martins Britto \\ silviobritto@faccat.br \\ http://orcid.org/0000-0001-5222-0126 \\ Universidade Luterana do Brasil - ULBRA/ Canoas/RS; Faculdades Integradas de \\ Taquara - FACCAT/Taquara/RS. \\ Brasil \\ Malcus Cassiano Kuhn \\ malcuskuhn@ifsul.edu.br \\ http://orcid.org/0000-0002-6001-2324 \\ Instituto Federal de Educação, Ciência e Tecnologia Sul-rio-grandense - IFSul Câmpus \\ Lajeado/RS. \\ Brasil \\ Arno Bayer \\ bayer@ulbra.br \\ https://orcid.org/0000-0001-7721-1162 \\ Universidade Luterana do Brasil - ULBRA/ Canoas/RS. \\ Brasil
}

Recibido: 2020-05-09; Aceptado: 2020-11-19

\begin{abstract}
Resumo
O tema deste artigo é a Matemática em periódico veiculado por colégio jesuíta do Rio Grande do Sul, no século XX. Seu objetivo é analisar dez artigos sobre Matemática, escritos pelo jesuíta Luiz Monteiro Reckziegel, em 1943, no periódico O Eco. Como o tema se insere na História da Educação Matemática no estado gaúcho, este estudo qualitativo e documental, ampara-se na pesquisa histórica. O Eco foi editado pelo Colégio Anchieta de Porto Alegre, de abril de 1914 até o final de 1969. Seu público-alvo era a comunidade escolar e a mocidade católica brasileira, apresentando-se conteúdos religiosos e morais e de formação geral. $\mathrm{O}$ jesuíta Luiz Roberto Reckziegel, formado em Filosofia e em Teologia, atuou no ensino de Ciências Exatas, escrevendo também artigos sobre Matemática e publicados no periódico $\mathrm{O}$ Eco. Os artigos de Reckziegel abordam procedimentos de cálculo envolvendo as operações aritméticas de adição, multiplicação, divisão e radiciação. Dessa forma, o autor buscava despertar o interesse e a curiosidade da mocidade estudantil, contribuindo para formação da juventude católica nos colégios onde esse periódico circulava.
\end{abstract}

Palavras-chave: História da Educação. Jesuítas. Revista. Matemática.

\section{MATEMÁTICAS EN ECO: ANÁLISIS DE ARTÍCULOS ESCRITOS POR EL JESUITA LUIZ MONTEIRO RECKZIEGEL}

\section{Resumen}

El tema de este artículo es Matemáticas en una revista publicada por un colegio jesuita en Rio Grande do Sul, en el siglo XX. Su objetivo es analizar diez artículos sobre Matemáticas, 
escritos por el jesuita Luiz Monteiro Reckziegel, en 1943, en la revista O Eco. Como el tema se inserta en la Historia de la Educación Matemática en el estado de Rio Grande do Sul, este estudio cualitativo y documental está respaldado por la investigación histórica. El Eco fue publicado por el Colégio Anchieta de Porto Alegre, desde abril de 1914 hasta finales de 1969. Su público objetivo era la comunidad escolar y la juventud católica brasileña, presentando contenido religioso y moral y educación general. El jesuita Luiz Roberto Reckziegel, graduado en Filosofía y Teología, trabajó en la enseñanza de Ciencias Exactas, también escribió artículos sobre Matemáticas y publicó en la revista O Eco. Los artículos de Reckziegel abordan los procedimientos de cálculo que involucran las operaciones aritméticas de suma, multiplicación, división, y radiación. Por lo tanto, el autor buscó despertar el interés y la curiosidad de la juventud estudiantil, contribuyendo a la formación de la juventud católica en las escuelas donde circulaba esta revista.

Palabras clave: Historia de la educación. Jesuitas. Revista. Matemáticas.

\title{
MATHEMATICS IN THE ECHO: ANALYSIS OF ARTICLES WRITTEN BY JESUIT LUIZ MONTEIRO RECKZIEGEL
}

\begin{abstract}
The theme of this article is Mathematics in a magazine published by a Jesuit college in Rio Grande do Sul, in the $20^{\text {th }}$ century. Its objective is to analyze ten articles on Mathematics, written by jesuit Luiz Monteiro Reckziegel, in 1943, in the periodical The Echo. As the theme is inserted in the History of Mathematics Education in the state of Rio Grande do Sul, this qualitative and documentary study is supported by historical research. The Echo was edited by Anchieta College of Porto Alegre, from April 1914 until the end of 1969. Its target audience was the school community and the Brazilian Catholic youth, presenting themselves religious and moral content and general formation. The jesuit Luiz Roberto Reckziegel, graduated in Philosophy and Theology, worked in the teaching of Exact Sciences, also writing articles on Mathematics and published in the magazine The Echo. Reckziegel's articles address calculation procedures involving the arithmetic operations of addition, multiplication, division and radication. In this way, the author sought to arouse the interest and curiosity of the student youth, contributing to the formation of Catholic youth in the schools where this magazine circulated.
\end{abstract}

Keywords: History of Education. Jesuits. Magazine. Mathematics.

\section{Introdução}

Este artigo aborda a Matemática no periódico O Eco, editado pelo Colégio Anchieta de Porto Alegre, no século passado. Tem como questão norteadora a Matemática veiculada pelos jesuítas, em escolas católicas brasileiras, no século XX. Trata-se de um recorte do estudo iniciado durante a elaboração da tese $O$ ensino da aritmética nas escolas paroquiais católicas e no Ginásio Nossa Senhora da Conceição de São Leopoldo nos séculos XIX e XX sob a ótica dos Jesuítas e aprofundado no estágio Pós-doutoral junto ao Programa de Pós-graduação em 
Ensino de Ciências e Matemática da Matemática - PPGECIM - da Universidade Luterana do Brasil - ULBRA, Canoas, Rio Grande do Sul (RS), Brasil.

Os trabalhos desenvolvidos pelas ordens religiosas que chegaram ao RS, após a segunda metade do século XIX, deixaram relevantes contribuições. Destacam-se os jesuítas entre essas ordens, por meio de trabalhos missionários, inicialmente, junto às colônias de imigrantes alemães católicos e, posteriormente, com a criação de uma rede de Ginásios e Seminários, que contribuíram para a formação da juventude gaúcha. Dentre os educandários criados pela ordem, destaca-se o Colégio Anchieta, com sede em Porto Alegre/RS.

O periódico O Echo foi editado pelo Colégio Anchieta, por meio da Typographia do Centro, localizada em Porto Alegre, no período de abril de 1914 a dezembro de 1931. A partir de 1932, passou a ser denominado $\mathrm{O}$ Eco, devido à reforma ortográfica ${ }^{1}$. O público-alvo do Eco era a comunidade escolar e a mocidade católica brasileira, pois, segundo os editores, não havia periódicos para os jovens estudantes. O periódico apresentava cultura geral e valores católicos, por isso era destinado para os jovens católicos.

Como a temática investigada se insere na História da Educação Matemática no RS, busca-se na pesquisa histórica, o suporte para discussão. No âmbito da História da Educação no estado gaúcho, os trabalhos de $\operatorname{Kreutz}(1991,1994)$, Rambo (1994, 1996), Leite (2005), Weiduschadt $(2007,2012)$ e Kuhn e Bayer (2017b) são destaques. Já na História da Educação Matemática no RS, destacam-se as pesquisas de Mauro (2005), Wanderer (2007), Kuhn (2015), Britto (2016), Kuhn e Bayer (2017a) e Britto, Bayer e Kuhn (2020).

Para investigar o periódico O Eco, visitas foram realizadas ao acervo particular do professor Luiz Osvaldo Leite ${ }^{2}$, em Porto Alegre, onde se encontram as edições do mesmo. Ao pesquisar as edições do periódico, observou-se a publicação de dez artigos sobre Matemática, escritos pelo jesuíta Luiz Monteiro Reckziegel, em 1943. Então, compilaram-se esses excertos, para posterior análise à luz do referencial teórico-metodológico. No estudo de documentos, Cellard (2008), destaca que:

\footnotetext{
${ }^{1}$ Em 30 de abril de 1931, entraram em acordo a Academia Brasileira de Letras e a Academia das Ciências de Lisboa, no sentido de ser adotado um único sistema ortográfico no Brasil e em Portugal. Esse entendimento teve a aprovação oficial do Governo Provisório, por força do Decreto no 28.128, de 15 de junho de 1931.

${ }^{2}$ Graduado em Filosofia e Teologia pela UNISINOS e UFRGS. Atuou na área de Filosofia, com ênfase em História da Filosofia, Ética e Psicologia. Foi diretor do Instituto de Psicologia da UFRGS e professor Emérito dessa Instituição, desde 2008. Foi aluno do Colégio Anchieta de 1944 a 1950 e atuou como professor nessa instituição, de 1956 a 1959 e de 1965 até a década de 1980.
} 
[...] o documento escrito constitui uma fonte extremamente preciosa para todo pesquisador. Ele é, evidentemente, insubstituível em qualquer reconstituição referente a um passado relativamente distante, pois não é raro que ele represente a quase totalidade dos vestígios da atividade humana em determinadas épocas. Além disso, muito frequentemente, ele permanece como o único testemunho de atividades particulares ocorridas num passado recente. (Cellard, 2008, p. 295).

Assim, com o objetivo de analisar artigos sobre Matemática, escritos por Luiz Monteiro Reckziegel, em 1943, no periódico O Eco, além do referencial teóricometodológico, são apresentadas a história do periódico, a biografia do autor e a abordagem dos conhecimentos matemáticos presentes nesses artigos.

\section{O aporte teórico-metodológico da investigação}

De acordo com Prost (2008), os fatos históricos são constituídos a partir de traços, de rastros deixados no presente pelo passado. Assim, o trabalho do historiador consiste em efetuar um trabalho sobre esses traços para construir os fatos. Desse modo, um fato não é outra coisa que o resultado de uma elaboração, de um raciocínio, a partir das marcas do passado. O autor considera o trajeto da produção histórica como sendo um interesse de pesquisa, a formulação de questões históricas legítimas, um trabalho com os documentos (edições do periódico O Eco) e a construção de um discurso que seja aceito pela comunidade.

Certeau (1982) define o fazer história, no sentido de pensar a história como uma produção. Para o autor, a história, como uma produção escrita, tem a tripla tarefa de convocar o passado que já não está em um discurso presente, mostrar as competências do historiador (dono das fontes, como o periódico O Eco) e convencer o leitor. Dessa forma, a prática histórica é prática científica enquanto a mesma inclui a construção de objetos de pesquisa, o uso de uma operação específica de trabalho e um processo de validação dos resultados obtidos, por uma comunidade.

O trabalho do historiador, de acordo com Certeau (1982), não se limita a produzir documentos, textos em uma nova linguagem. Isso ocorre porque no seu fazer pesquisa há um diálogo constante do presente com o passado, e o produto desse diálogo consiste na transformação de objetos naturais em cultura. Serra (2010) acrescenta que o trabalho com periódicos educacionais: 
Possibilita a reconstrução histórica das práticas específicas desenvolvidas pelos autores, como também permite redesenhar os leitores visados por tais práticas, portanto a importância do estudo dos periódicos na sua materialidade. A partir do próprio impresso é possível recompor os projetos específicos como estratégias que visam a públicos leitores característicos. (Serra, 2010, p. 25).

Conforme Valente (2007), há uma infinidade de materiais que, junto com os livros didáticos, podem permitir compor um quadro da Educação Matemática de outros tempos. Para o autor, realizar o estudo histórico da Matemática escolar exige que se devam considerar os produtos dessa cultura do ensino de Matemática, que deixaram traços que permitem o seu estudo, como o periódico O Eco, principal fonte documental desta investigação.

\section{O periódico O Eco e sua história}

A presença dos jesuítas no estado gaúcho acontece em três momentos, conforme ilustrado na Figura 1:

Figura 1. Os jesuítas no Rio Grande do Sul

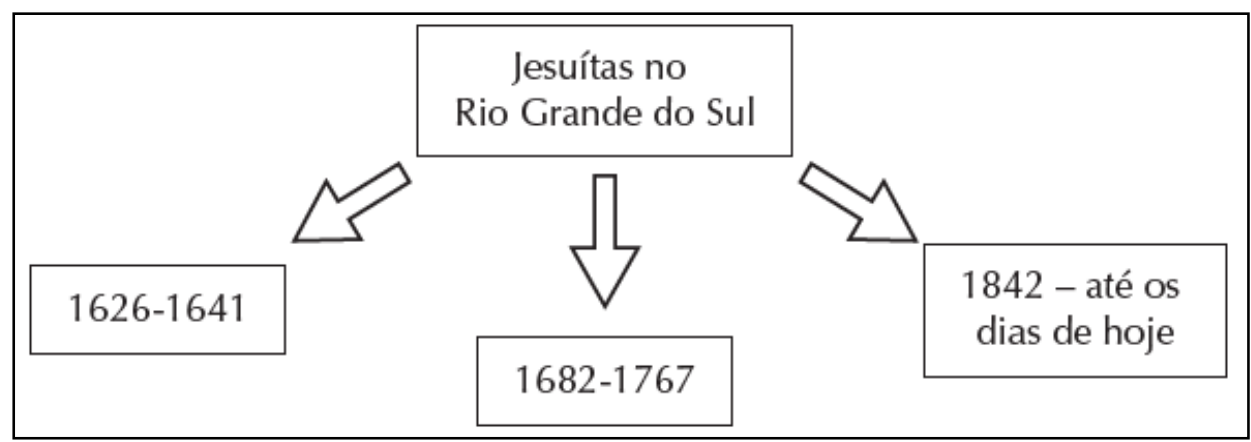

Fonte: Dos autores.

Nos dois primeiros momentos (1626-1641 e 1682-1767), sua presença ocorreu junto aos índios ${ }^{3}$ Guaranis, nas chamadas reduções jesuíticas ${ }^{4}$. Suas ações foram significativas para a história do RS, destacando-se a introdução do gado, a fundação de cidades, além de um notável empreendimento, junto aos Guaranis, ensinando os benefícios de uma vida em sociedade e em família. Outro aspecto a ser destacado trata-se dos legados artísticos e culturais

\footnotetext{
3 Nome atribuído a alguns nativos levados por Colombo a Portugal, que ele chamou de índios, pois ele considerava-os habitantes das Índias.

4 A palavra "reduzir" era usada no sentido de purificar, limpar. [...] Assim o local onde ficavam os índios "reduzidos", ou seja, limpos pelo batismo, era chamado de redução (Britto, Bayer e Kuhn, 2020).
} 
marcados por suas construções e obras. Isso se verificou até a expulsão dos jesuítas desse território e de seus domínios, dizimando a etnia Guarani (Britto, 2016).

O retorno dos jesuítas ao RS, em 1842, constituiu-se o terceiro momento. Destacou-se pela ação missionária e ensino, inicialmente, junto às colônias de imigrantes alemães. Aos poucos, os padres foram se aliando aos colonos e com os professores paroquiais, prestando assistência espiritual e melhorias do ensino nas escolas e na formação dos professores. Conforme Britto (2016), os jesuítas pouco atuaram como professores, mas auxiliando-os no planejamento e na execução de suas aulas a partir de encontros de formação, além da criação de uma escola normal, visando formar e qualificar os futuros professores. Segundo Rambo (1994), as escolas paroquiais estiveram sob o comando da ordem por, aproximadamente, 70 anos, contribuindo para melhoria da qualidade do ensino nas colônias de imigrantes.

Em 1869, os jesuítas criaram o Colégio Nossa Senhora da Conceição ${ }^{5}$, em São Leopoldo, em nível secundário, constituindo-se um dos marcos no processo de instrução no RS. Objetivava-se, inicialmente, formar padres e professores para as comunidades rurais de imigrantes alemães. Com professores extremamente qualificados, em sua maioria, provenientes da Alemanha, devido ao Kulturkampf $f^{6}$, a escola colheu os resultados obtidos por seus alunos, durante os 43 anos de atividades. No campo da Matemática, identificou-se, segundo relatórios desse ginásio, a presença de livros didáticos elaborados pelos próprios padres jesuítas do Colégio Conceição. Em 1911, o Colégio perde o status de ginásio equiparado, transformando-se apenas em uma escola. No ano de 1912, encerra suas atividades em São Leopoldo, concentrando-se nas ações da ordem no Anchieta, em Porto Alegre, pois a maioria dos estudantes do Colégio Conceição residia na capital gaúcha (Britto, 2016).

O Anchieta surge no ano de 1890, como externato do Colégio Conceição, em Porto Alegre (Relatório do Colégio Anchieta, 1914). Mantido e dirigido pelos padres da Companhia de Jesus, foi fundado como um simples colégio. No princípio, com a denominação de Colégio dos Padres, era destinado somente a meninos. No ano de 1897, o Colégio muda de nome, passando a se chamar São José. A denominação que o faria entrar para história no RS, como

\footnotetext{
${ }^{5}$ O Colégio Nossa Senhora da Conceição, após ser equiparado ao Ginásio Nacional D. Pedro II, em 1900, passa a chamar-se Ginásio Nossa Senhora da Conceição, sendo esse o primeiro Ginásio do RS (O Eco, 1965, v. 6). "O Colégio Conceição, fundado em 1870, tornou-se o mais afamado estabelecimento de ensino secundário do sul do Brasil, por onde passaram mais de 5000 alunos dos quais muitos galgaram elevados postos da Igreja, governo, exército e polícia" (O Eco, 1940, v. 10, p. 299).

${ }^{6}$ Kulturkampf ou luta pela cultura foi um movimento anticlerical alemão do século XIX, iniciado por Otto Von Bismarck, chanceler do Império alemão em 1872.
} 
Colégio Anchieta, aconteceu em 1901, em homenagem ao Padre José de Anchieta, um fiel intérprete e seguidor da espiritualidade de Santo Inácio de Loyola, fundador da congregação dos jesuítas.

Segundo Leite (2005), em 1908, como estabelecimento independente, o Anchieta foi equiparado ao Colégio Dom Pedro II. Já em 1911, torna-se estabelecimento autônomo, devido à reforma ocasionada pela Lei Orgânica do mesmo ano. A partir de 1942, a denominação do Colégio passou a ser Colégio Anchieta. “Após 1963, com o início da transferência dos alunos para o novo prédio, adotou-se o princípio da coeducação, com rapazes e moças estudando lado a lado, quando a tradição nos colégios confessionais mantinha a separação dos sexos" (Colégio Anchieta, 1990, p. 47). O Colégio Anchieta ainda está em funcionamento e completará, este ano, 130 anos de atividades junto à comunidade porto-alegrense.

Em 1914, no seu sétimo ano de atividade de forma independente, o Anchieta, como é conhecido, passa a editar o periódico $\mathrm{O}$ Echo, destinado à mocidade brasileira, abordando temas pertinentes em suas diferentes épocas de circulação. Sua publicação aconteceu pela Typografia do Centro, localizada em Porto Alegre, no período de abril de 1914 até o final de 1969. A partir de 1932, o periódico passa a ser denominado O Eco, devido à reforma ortográfica. Segundo Leite (2018), a designação do nome desse periódico se dá:

No sentido de que os ensinamentos ressoassem fortemente, produzissem eco nos jovens, nas famílias, em toda a população católica. Para os seus precursores, todos de origem alemã, essa deveria ter o mesmo efeito do eco produzido nos Alpes da Europa, onde em sua maioria tiveram sua infância. Nesses locais, os pastores caminhavam pelas montanhas e ao chamarem seus animais produziam sons, através de instrumentos que ecoavam por toda a região, sendo algo típico que a população costumava a ouvir. (Leite, 2018, informação $\operatorname{verbal}^{7}$ ).

O Eco tinha, inicialmente, circulação mensal, e posteriormente, circulação bimestral, destinado à comunidade escolar, principalmente, à mocidade brasileira, conforme inscrição na capa dos periódicos publicados, reunindo diversos temas, entre eles a Matemática. Na Figura 2, apresentam-se capas do periódico investigado em diferentes períodos, inicialmente com a denominação O Echo, até dezembro de 1931, e depois a denominação O Eco.

\footnotetext{
${ }^{7}$ Entrevista concedida por Luiz Osvaldo Leite, em Porto Alegre/RS, no dia 16 de março de 2018.
} 
Figura 2. Capas do periódico O Echo e O Eco
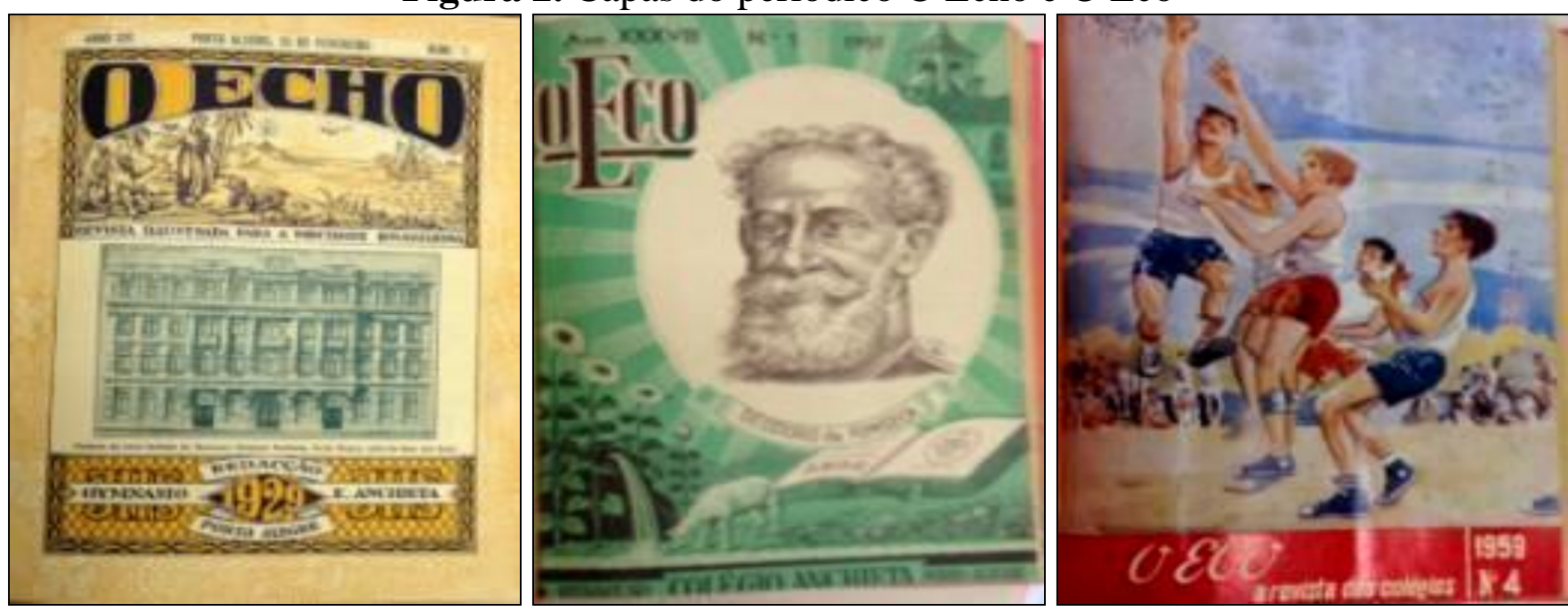

Fonte: O Echo, 1929; O Eco, 1951; O Eco, 1959.

Nas duas primeiras décadas, a capa do periódico apresentou poucas alterações. Já nos anos seguintes, verificaram-se mudanças com frequência, apresentando, por exemplo, imagem de colégios pelo país (objetivando buscar assinantes), personagens da história do Brasil, esportes, profissões, pontos turísticos do Brasil, entre outros. O objetivo do periódico era:

Há um número de revistas de diversas espécies: revistas para todos sem distincção de classe, e revistas especiaes para as diversas classes de pessoas. Há revistas jurídicas, há revistas médicas, há revistas commerciaes e industriaes, há revistas marítimas e militares, há revistas eclesiásticas, até para a infância há não sei quantas revistas infantis. Só a mocidade não tem uma revista própria, uma revista feita especialmente para ella. É uma lacuna por demais sensível e que urge preencher. Pois, essa classe poderosa em número, essa classe a que se dá tal importância que é chamada esperança da pátria, será admissível que careça de uma vantagem de que gozam os outros? Eis a origem do "ECHO": nasceu da necessidade evidente de ter também a mocidade uma revista própria, exclusivamente sua. (O Echo, 1915, v. 1, p. 1) ${ }^{8}$.

Editado, inicialmente, a cada vinte e cinco dias, com o primeiro número em fevereiro e o último em novembro de cada ano, o periódico totalizava 12 edições por ano. Um dos periódicos, normalmente o último do ano, abrangia dois números, já que em janeiro ele não era editado em virtude das férias escolares. A $1^{\mathrm{a}}$ edição foi registrada em abril de 1914:

Sahiu á luz o $1^{\circ}$ número do $\mathrm{O} \mathrm{ECHO}$, revista mensal illustrada, na qual além de muitos colaboradores competentes que, em suas columnas, se dedicaram aos interesses da mocidade estudiosa do Brasil, os próprios alunos debaixo da direção de seus mestres, se estréam no manejo da pena. No suplemento "Echos dos Collegios" trocam os jovens

\footnotetext{
${ }^{8} \mathrm{Na}$ citação se mantém a ortografia da fonte original.
} 
escriptores impressões e notícias que particularmente affectam a vida internas dos collegios. (Relatório do Colégio Anchieta, 1914, p. 28).

Cada edição era a continuação da anterior, inclusive na paginação, sendo que durante o ano eram publicadas de 350 a 430 páginas. O ano representava um volume, destacado em números romanos, e o mês era representado por um número natural. Os diferentes exemplares traziam artigos escritos e muitas gravuras, sendo sua estruturação semelhante em todas as edições. Nos 40 primeiros anos, a edição tinha um formato de 16 cm x 24 cm. Já em 1963, o periódico ficou maior, com formato $32 \mathrm{~cm}$ x $23 \mathrm{~cm}$, passando a ter circulação bimestral.

Os artigos no periódico O Eco trazem poemas, notícias, reflexões de padres e professores, conferências, variedades, anedotas, contos, publicações de premiações de alunos por redação ou por competição esportiva, anúncios de propagandas, Ciências, invenções, Artes, Astronomia, Matemática, reforma da Língua Portuguesa, descobertas, sendo que, após 1950, começam a aparecer artigos direcionados à prática esportiva, como futebol, bola ao cesto, entre outros. De modo ilustrativo, apresenta-se o índice do volume 1 do periódico O Eco de 1942 com as temáticas abordadas:

1 Assuntos Religiosos/ 2 Biografia e Traços Biográficos/ 3 Ciências Naturais e Técnicas/ 4 Artes, Matemática e Curiosidades/ 5 Indústria, Comércio, Etnografia e Viagens/ 6 História e Geografia/ 7 Assuntos Pedagógicos/ 8 História, Contos, Lendas e Anedotas/ 9 Poesias, Músicas e Aforismos/ 10 Linguística/ 11 Bibliografia/ Teatro e Humanismo. (O Eco, 1942, v. 1, p. 8).

Acrescenta-se que no periódico O Eco também há ilustrações, como fotografias de colégios, imagens de papas, padres, alunos, ex-alunos, personagens da história do Brasil, santos da Igreja Católica, paisagens, ilustrações de textos, cenários de guerra, futebol e humor.

Conforme Leite (2018), O Eco encerra a circulação em 1969, tendo como principal fator, a falta de leitores. Inicialmente, em 1914, havia poucas publicações de periódicos, porém, com o passar do tempo, outros semelhantes passaram a ser publicados no Brasil, tais como: O Cruzeiro, A Cigarra e revistas em quadrinhos. Em virtude dos recursos financeiros, essas publicações eram mais atrativas, visualmente, uma diferença em relação ao Eco.

Ainda de acordo com Leite (2018), o corpo de redatores era constituído por um diretor e colaboradores, voluntários, que enviavam artigos para as edições do Eco. Já nos demais periódicos, havia uma equipe de redatores e técnicos, sendo todos remunerados. Acrescentase, segundo Leite (2018), que: 
A revista ficou pesada demais para a época, até mesmo nós, como alunos do Anchieta, ela não despertava mais interesse, as matérias eram pesadas para a época. Até mesmo o espaço destinado a humor tornou-se de certa forma ingênuo. Os seminaristas adoravam, já os demais jovens não, até ridicularizavam. (Leite, 2018, informação verbal9).

Diante desses fatores, o periódico não pode mais se manter em circulação. Jornais diários, cronistas, fotos, diários esportivos e cinema ganharam seu espaço. Os novos periódicos traziam páginas sobre filmes e notícias e, com isso, O Eco ficou para trás. De qualquer forma, O Eco cumpriu sua missão, para a época que esteve em circulação, levando instrução para a juventude católica, por mais de cinco décadas.

\section{A biografia de Luiz Monteiro Reckziegel}

Ao pesquisar as edições do periódico O Eco, no acervo particular do professor Luiz Osvaldo Leite, em Porto Alegre, a publicação de dez artigos sobre Matemática, escritos por Luiz Monteiro Reckziegel, em 1943, chamou a atenção. Isso, pois durante mais de meio século de edições do periódico, identificou-se a Matemática presente em seções recreativas, por meio de perguntas, problemas, desafios e curiosidades, enquanto que os artigos de Reckziegel trazem explicações sobre procedimentos para cálculos escritos e mentais, associadas a elementos do cotidiano do público alvo do periódico.

De acordo com Leite (2019), a partir de estudos realizados em catálogos e boletins informativos dos jesuítas, Luiz Monteiro Reckziegel nasceu em 9 de junho de 1914. Foi professor no Colégio Anchieta de Porto Alegre e no Seminário de Gravataí. Ingressou na ordem dos jesuítas em fevereiro de 1931. Cursou Filosofia no período de 1937 a 1941 . Nos anos de 1942 e 1943, cursou Teologia. Por motivos desconhecidos, interrompeu o curso em 1944 e 1945, para assessorar o Reitor do Colégio Máximo Cristo Rei, de São Leopoldo, e atuar como bibliotecário, em 1946. No ano de 1947, retomou o $3^{\circ}$ ano do curso de Teologia. Após esse ano, não há mais registros sobre o mesmo, em documentos da ordem. Segundo relatos de um familiar de Reckziegel, este não se ordenou padre e teria morrido afogado (Leite, 2019).

Como professor, segundo Leite (2019), Reckziegel lecionou Trigonometria, Geometria, Física, Química, Álgebra e História Natural. Na época, a escolha pela disciplina a

\footnotetext{
${ }^{9}$ Entrevista concedida por Luiz Osvaldo Leite, em Porto Alegre/RS, no dia 16 de março de 2018.
} 
ser lecionada era pelo gosto e pela inclinação, pois não havia uma formação específica. Mas, no curso de Filosofia havia o estudo de questões conexas com as Ciências Exatas e Naturais.

Os dez artigos escritos pelo jesuíta Luiz Monteiro Reckziegel ${ }^{10}$ foram publicados no periódico O Eco, em 1943, enquanto o autor cursava o $2^{\circ}$ ano do curso Teologia. Esses artigos foram compilados e seus títulos são apresentados no Quadro 1:

Quadro 1. Artigos sobre Matemática escritos por Luiz Monteiro Reckziegel em 1943

\begin{tabular}{|l|l|l|}
\hline Edição de 1943 & Título do artigo & Temática do artigo \\
\hline V. 1, p. 10 & Multiplicação simplificada & Multiplicação \\
\hline V. 2, p. 65 & Janela em movimento & Multiplicação \\
\hline V. 3, p. 103 & As guirlandas da minha casa & Multiplicação \\
\hline V. 4, p. 127 & O esqueleto da multiplicação & Multiplicação \\
\hline V. 5, pp. 167-168 & Divisão simplificada & Divisão \\
\hline V. 6, pp. 200-201 & $\begin{array}{l}\text { Dupla simplificação da radiciação - } \\
\text { I. Da raiz quadrada }\end{array}$ & Radiciação - Raiz quadrada \\
\hline V. 7, pp. 228-230 & $\begin{array}{l}\text { Dupla simplificação da radiciação - } \\
\text { II. Da raiz cúbica }\end{array}$ & Radiciação - Raiz cúbica \\
\hline V. 8, p. 258 & Somar pelos dedos & Adição \\
\hline V. 9, p. 289 & A máquina do Chiquinho & Multiplicação \\
\hline V. 11, p. 380 & Por que funciona? & Multiplicação \\
\hline
\end{tabular}

Fonte: Dos autores.

Observou-se que esses artigos abordam procedimentos para cálculos escritos e mentais, envolvendo as operações aritméticas de adição, multiplicação, divisão e radiciação (raiz quadrada e raiz cúbica), conforme detalhado na seção seguinte.

\section{A Matemática nos artigos escritos por Reckziegel}

Nos três primeiros artigos, Reckziegel procura trabalhar a multiplicação de uma forma “simplificada". Para tanto, por meio de exemplos e associações com elementos do cotidiano, como vagões de trem, janelas móveis e guirlandas, mostra procedimentos para resolver cálculos de multiplicação envolvendo números com três algarismos.

Inicialmente, o autor explica a multiplicação de 321 por 567, utilizando-se de movimentos de trem e passeio em uma gare ${ }^{11}$, escrevendo, separadamente, os algarismos do número 567 em vagões de trem e do número 321 numa gare, conforme ilustrado na Figura 3:

\footnotetext{
${ }^{10}$ Segundo os catálogos dos jesuítas, desde o momento em que o candidato ingressava no noviciado, $2^{\mathrm{a}}$ etapa do processo de formação de um jesuíta, ele já era um jesuíta, mesmo não tendo sido ordenado padre (Leite, 2019).
} 
Figura 3. Multiplicação de 321 x 567 associada com o movimento de trem

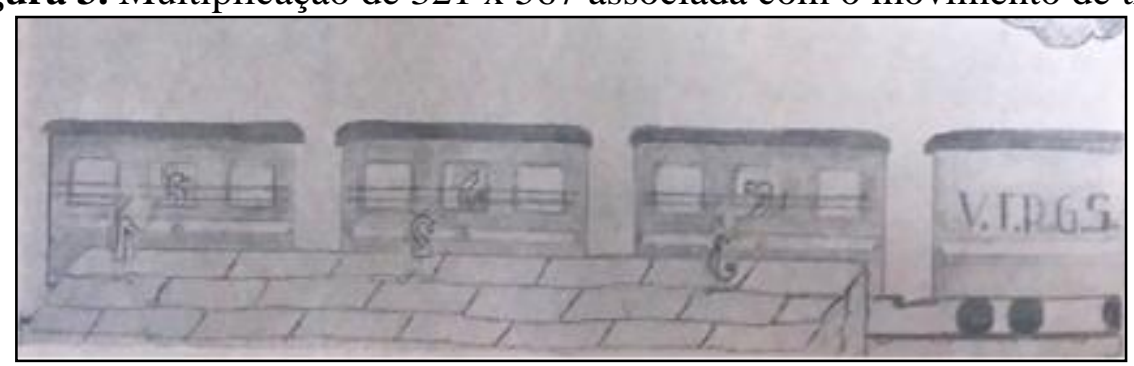

Fonte: O Eco, 1943, v. 1, p. 10.

À medida que o trem se movimenta, e os vagões numerados começam a encontrar os algarismos indicados na gare, realiza-se o processo da multiplicação, em cinco etapas:

$1^{\text {a) }}$ Quando o vagão numerado com o 7 encontra o 1 na gare, faz-se 7 x $1=7$ unidades.

$2^{\mathrm{a}}$ ) Quando o vagão numerado com o 7 encontra o 2 na gare e o vagão numerado com o 6 encontra o 1 na gare. Nesse movimento, multiplicam-se $7 \times 2+6 \times 1=14+6=20$ dezenas, que equivale a 2 centenas mais 0 dezenas.

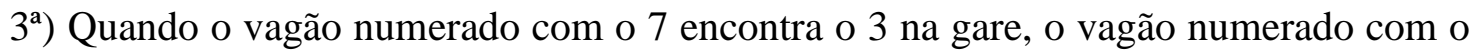
6 encontra o 2 na gare e o vagão numerado com o 5 encontra o 1 na gare. Logo, multiplicamse $7 \times 3+6 \times 2+5 \times 1=21+12+5=38$ centenas. Adicionando-se as 2 centenas reservadas do movimento anterior, chega-se em $38+2=40$ centenas, equivalente a 4 unidades de milhar mais 0 centenas.

$4^{\mathrm{a}}$ ) Quando o vagão numerado com o 6 encontra o 3 na gare e o vagão numerado com o 5 encontra o 2 na gare. Então, multiplicam-se $6 \times 3+5 \times 2=18+10=28$ unidades de milhar. Acrescentando-se as 4 unidades de milhar reservadas da etapa anterior, totaliza-se $28+4=32$ unidades de milhar, equivalente a 3 dezenas de milhar mais 2 unidades de milhar.

$5^{\text {a) }}$ Quando o vagão numerado com o 5 encontra o 3 na gare, realiza-se 5 x $3=15$ dezenas de milhar, que somadas com as 3 dezenas de milhar reservadas do movimento anterior, totalizam 18 dezenas de milhar, equivalendo a 1 centena de milhar mais 8 dezenas de milhar.

Dessa forma, considerando-se os movimentos realizados nas cinco etapas descritas, o produto 321 x 567 resulta em 182007.

No segundo artigo, o autor apresenta a mesma multiplicação fazendo associação com uma janela em movimento, conforme ilustração mostrada na Figura 4. Segundo o autor, “à

\footnotetext{
${ }^{11}$ Embarcadouro e desembarcadouro das estações de estrada de ferro.
} 
primeira vista você entende, que estes traços representam os raios de luz que fazem os algarismos se enxergarem pela janela móvel" (O Eco, 1943, v. 2, p. 65).

Figura 4. Multiplicação de 321 x 567 associada à janela móvel

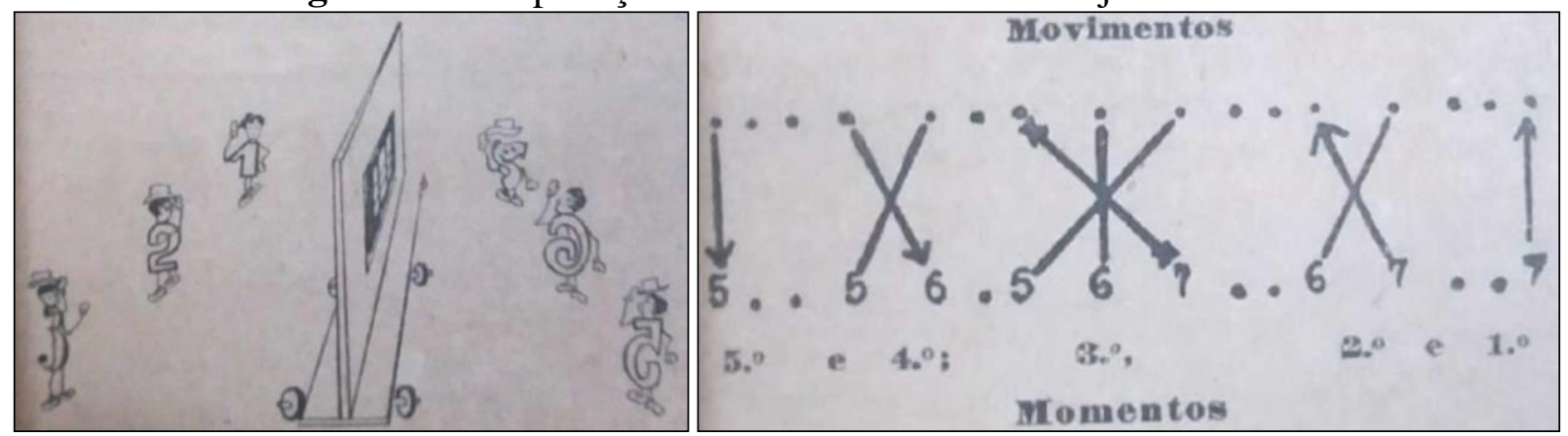

Fonte: O Eco, 1943, v. 2, p. 65.

Portanto, à medida que essa janela se movimenta, os algarismos dos fatores se enxergam, realizando-se os cinco momentos de multiplicação parcial (Figura 4), de forma semelhante ao processo desenvolvido nas cinco etapas relacionadas ao movimento do trem na gare (Figura 3).

O autor exemplifica a multiplicação de 324 por 567, no seu terceiro artigo, através de uma representação semelhante a guirlandas ${ }^{12}$, conforme apresentado na Figura 5.

Figura 5. Multiplicação de 324 x 567 associada à representação de guirlandas

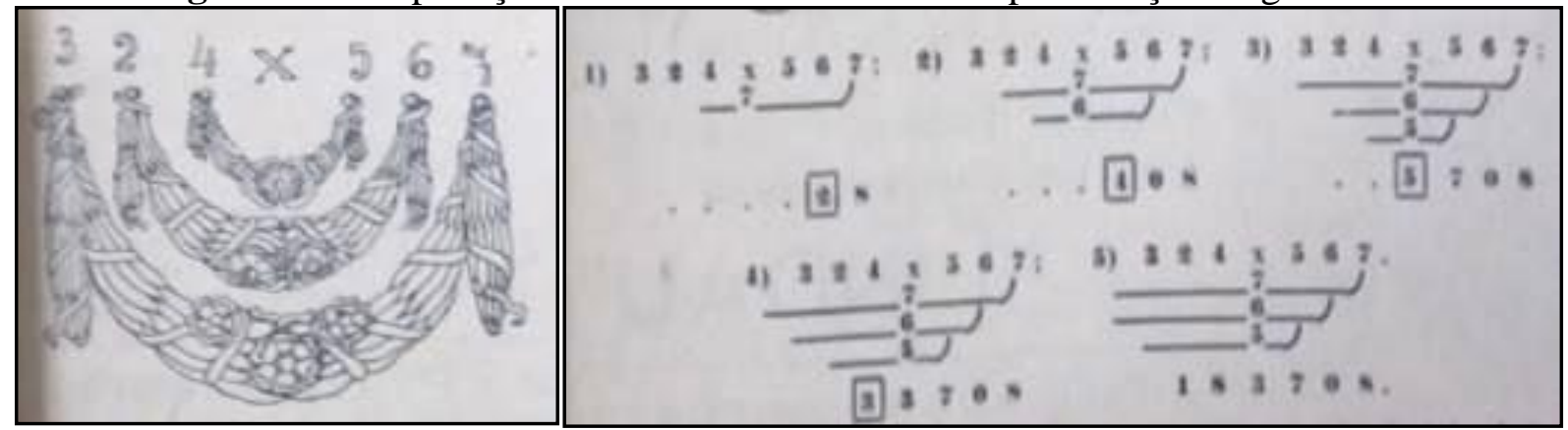

Fonte: O Eco, 1943, v. 3, p. 103.

Esse procedimento é semelhante aos abordados nos dois primeiros artigos do autor. Observa-se que nesse modo simplificado de cálculo da multiplicação 324 x 567, inicia-se determinando o algarismo das unidades do produto e a reserva para a ordem das dezenas (etapa 1). Em seguida, o algarismo das dezenas e a reserva para a ordem das centenas (etapa 2); depois o algarismo das centenas e a reserva para a ordem das unidades de milhar (etapa 3); o algarismo unidades de milhar e a reserva para as dezenas de milhar (etapa 4); por fim, o

\footnotetext{
${ }^{12}$ As guirlandas são um ornamento feito de flores, frutas ou ramagens entrelaçadas. São usadas, especialmente, em período de Natal.
} 
algarismo das dezenas de milhar e da centena de milhar (etapa 5), encontrando-se que $324 \mathrm{x}$ 567 resulta em 183708. Já os comprimentos diferenciados das guirlandas estão associados às posições ocupadas pelos algarismos em cada fator e, na prática, aos arcos de lápis que são feitos durante as multiplicações parciais (Figura 5).

Depois de apresentar o procedimento da "multiplicação simplificada", nos três primeiros artigos, Reckziegel aborda outro modo de multiplicar, chamando-o de "esqueleto da multiplicação", mostrado na Figura 6. De acordo com o autor (O Eco, 1943, v. 4), esse modelo de multiplicação também era usado por Malba Tahan ${ }^{13}$, no livro Histórias e Fantasias da Matemática (1939).

Figura 6. Esqueleto da multiplicação para 321 x 567

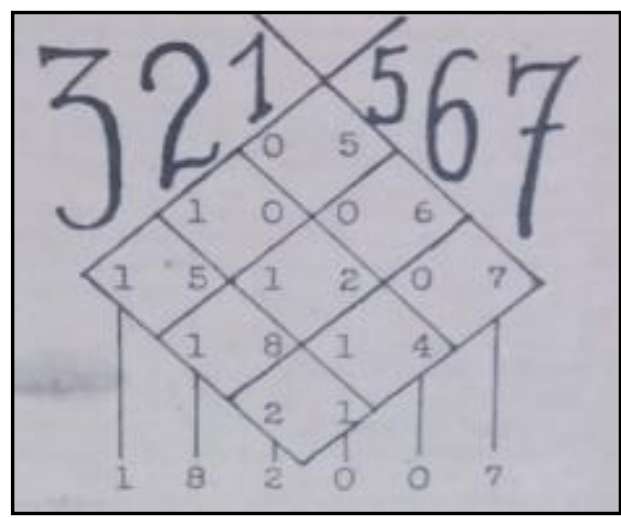

Fonte: O Eco, 1943, v. 4, p. 127.

Após escrever o multiplicando e o multiplicador do lado de fora e ao longo dos dois lados do retângulo, como representado na Figura 6, inicia-se a multiplicação, ocupando o algarismo das dezenas desse produto, o canto da esquerda, e o algarismo das unidades, o canto direito em cada quadrinho. Assim, formam-se colunas verticais de algarismos, cujas somas originam os algarismos do resultado.

Nesse modelo, encontram-se duas formas de obter a multiplicação: observando-se primeiro as faixas da esquerda para a direita, que descem oblíquas, em seguida, as que sobem oblíquas e, por fim, as séries verticais de quadrinhos; irá se encontrar as mesmas somas, logo, conclui-se que multiplicando 567 por 321 e 321 por 567, chega-se ao mesmo resultado,

\footnotetext{
${ }^{13}$ O professor brasileiro Júlio Cesar de Mello e Souza (1895-1974), mais conhecido por Malba Tahan, publicou livros didáticos com cunho menos rígido, preocupando-se em atrair crianças e jovens para o mundo da Matemática. A obra O Homem que calculava, de 1938, talvez seja seu livro mais conhecido, teve inúmeras edições e utilizado por várias gerações.
} 
conforme ilustrado na Figura 7. Por fim, Reckziegel faz uma analogia entre o esqueleto da multiplicação e a multiplicação simplificada.

Figura 7. Analogia entre o esqueleto da multiplicação e a multiplicação simplificada

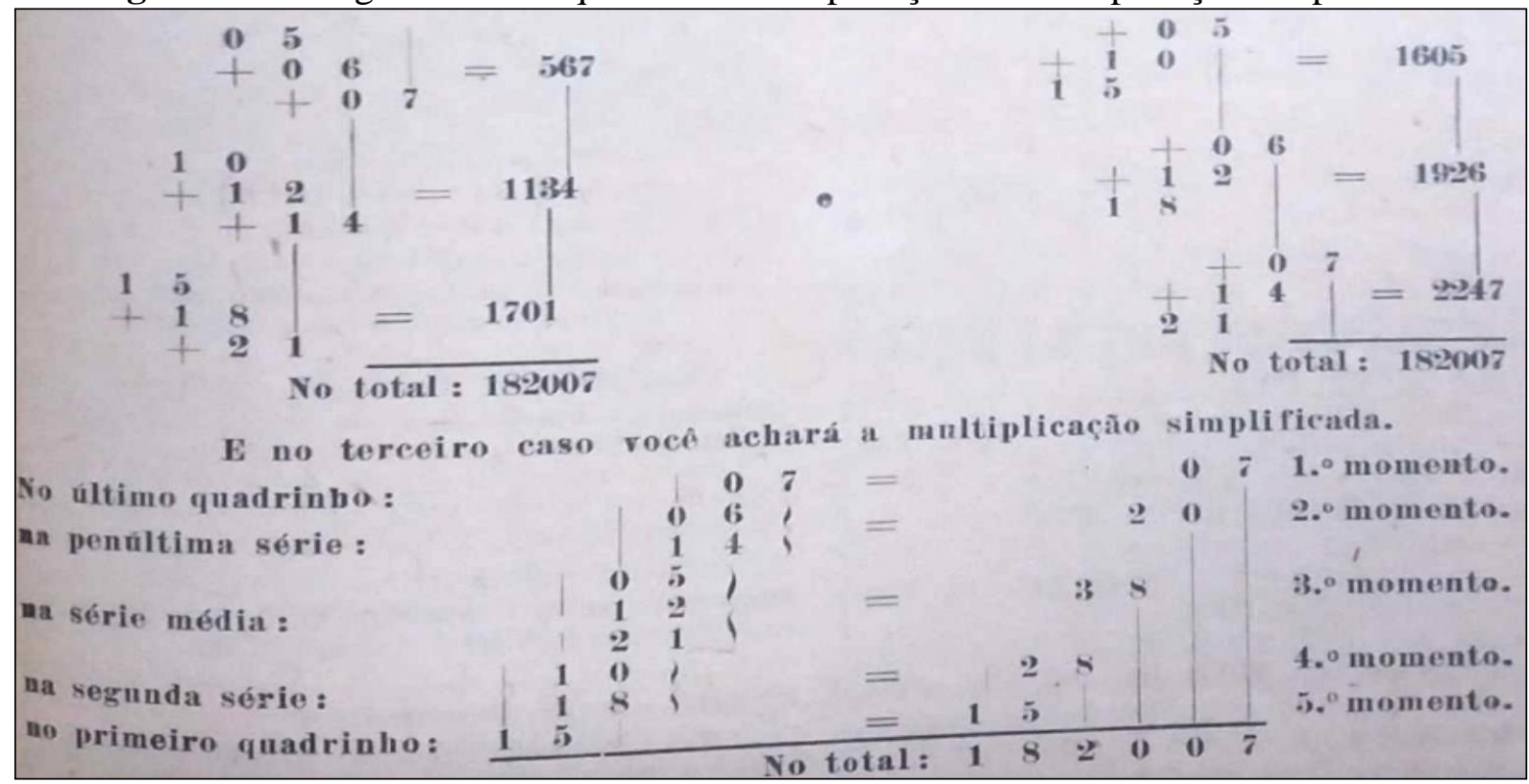

Fonte: O Eco, 1943, v. 4, p. 127.

Observa-se que a soma dos resultados verticais obtidos no esqueleto da multiplicação (Figura 6) correspondem, respectivamente, às multiplicações parciais dos movimentos do trem numa gare, representados na Figura 3, da associação com uma janela em movimento (Figura 4) e da representação de guirlandas (Figura 5). Considerando-se as explicações apresentadas nos artigos, pode-se dizer que o esqueleto da multiplicação vem a ser uma forma de validação da multiplicação simplificada, sugerida pelo autor. Ficaria a cargo do leitor, utilizar um ou outro procedimento nos cálculos envolvendo multiplicações, embora, para Reckziegel, "as vantagens da multiplicação simplificada saltam aos olhos" (O Eco, v. 4, p. 127).

No quinto artigo, intitulado "Divisão simplificada", o autor apresenta um procedimento para cálculo de divisão, com o exemplo $156969 \div 321$, conforme mostrado na Figura 8 : 
Figura 8. Divisão simplificada de 156969 por 321

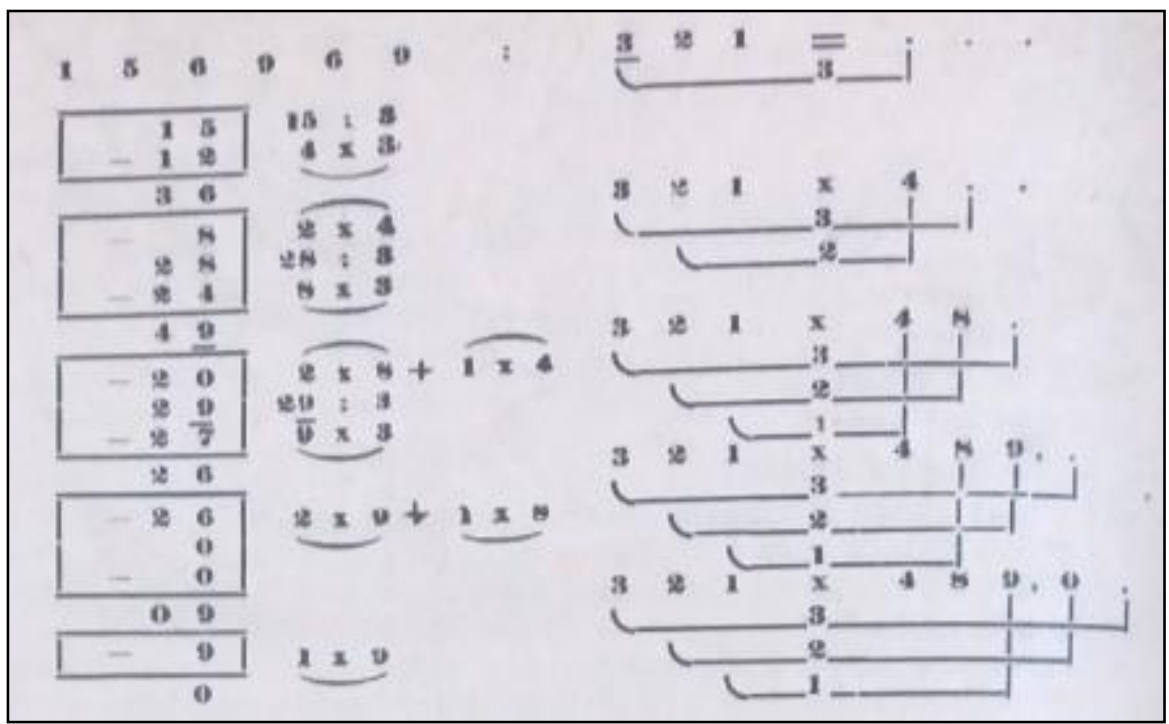

Fonte: O Eco, 1943, v. 5, p. 168.

Ao resolver essa divisão ${ }^{14}$, o autor faz uma associação com a representação de guirlandas, tratada no seu terceiro artigo sobre multiplicação simplificada. Observa-se que são realizadas, em etapas, divisões sucessivas por 3, que é o primeiro algarismo do divisor 321. Por isso, o autor sublinha o algarismo $\underline{3}$ do divisor e sugere deixar o mesmo quantitativo de algarismos não sublinhados no dividendo. Dessa forma, no dividendo sublinha 1569 e se inicia a divisão:

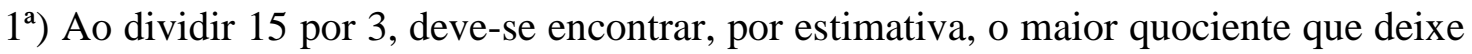
algum resto e permita a continuidade do cálculo. Nesse caso, seria o 4 que deixa resto 3. Então, baixa-se o 6, para dar andamento à próxima etapa.

$\left.2^{\mathrm{a}}\right)$ É iniciada com a associação à representação de uma guirlanda, observando-se que o algarismo 3 do divisor sustenta o extremo maior, em busca do próximo algarismo do quociente, enquanto o algarismo 2 do divisor é ligado ao algarismo 4 do quociente, resultando no produto 2 x $4=8$, que é subtraído de 36. Então, a diferença 28 passa a ser dividida por 3 . Novamente, é preciso encontrar, por estimativa, o maior quociente que deixe algum resto e permita a continuidade do cálculo. Nesse caso, seria o 8 que deixa resto 4. Então, baixa-se o 9, para dar andamento à terceira etapa. Como esse 9 é o último algarismo sublinhado no dividendo, deve-se colocar a vírgula após o próximo algarismo do quociente encontrado.

\footnotetext{
${ }^{14}$ Num primeiro momento, Reckziegel pensava que estava mostrando um modo simplificado de fazer a divisão, de sua autoria, mas encontrou procedimento semelhante em um livro do Sr. Dr. F. Ferol, um engenheiro mais conhecido na Europa do que no Brasil (O Eco, 1943, v. 5).
} 
$3^{\text {a }) ~ N o v a m e n t e ~ e ́ ~ f e i t a ~ a ~ a s s o c i a c ̧ a ̃ o ~ c o m ~ a ~ r e p r e s e n t a c ̧ a ̃ o ~ d e ~ g u i r l a n d a, ~ o b s e r v a n d o ~ q u e ~}$ o algarismo 3 do divisor sustenta o extremo maior em busca do próximo algarismo do quociente, enquanto o algarismo 2 do divisor é ligado ao algarismo 8 do quociente e o algarismo 1 do divisor é ligado ao algarismo 4 do quociente, originando-se os produtos 2 x $8+$ $1 \times 4=16+4=20$, que é subtraído de 49. Logo, a diferença 29 passa a ser dividida por 3 . Novamente, é preciso encontrar, por estimativa, o maior quociente que deixe algum resto e permita a continuidade do cálculo. Encontra-se o 9, que deixa resto 2, e se coloca a vírgula no quociente. Em seguida, baixa-se o 6, para dar andamento à quarta etapa.

$\left.4^{a}\right)$ Ao fazer a associação com a representação de guirlanda, o algarismo 3 do divisor continua sustentando o extremo maior em busca do próximo algarismo do quociente, enquanto o algarismo 2 do divisor é ligado ao algarismo 9 do quociente e o algarismo 1 do divisor é ligado ao algarismo 8 do quociente, originando-se os produtos 2 x $9+1$ x $8=18+8=26$, que é subtraído de 26, resultando na diferença 0 . Então, a diferença 0 passa a ser dividida por 3. Novamente, é preciso encontrar, por estimativa, o maior quociente que deixe algum resto e permita a continuidade do cálculo. No caso seria o 0 que deixa resto 0 . Então, baixa-se o 9 , para dar andamento à última etapa.

$5^{\text {a) }}$ Ao fazer a associação com a representação de guirlanda, o algarismo 3 continua sustentando o extremo maior em busca do possível próximo algarismo do quociente, enquanto o algarismo 2 do divisor é ligado ao algarismo 0 do quociente e o algarismo 1 do divisor é ligado ao algarismo 9 do quociente, originando-se os produtos 2 x $0+1 \times 9=0+9=9$, que é subtraído de 9, resultando na diferença 0. Então, chega-se ao final do cálculo, concluindo-se que $156969 \div 321=489$.

O leitor deste artigo poderia se perguntar por que o maior quociente não seria o 9 , na $2^{\mathrm{a}}$ etapa do exemplo acima? Caso fosse o quociente 9, deixaria resto 1. Ao baixar o 9, ter-se-ia 19 e baseando-se na associação com a guirlanda, o algarismo 2 do divisor seria ligado ao algarismo 9 do quociente e o algarismo 1 do divisor seria ligado ao algarismo 4 do quociente, originando-se os produtos 2 × $9+1$ × $4=18+4=22$, que não poderia ser subtraído de 19. Por isso, deve-se estimar o quociente inferior seguinte.

Reckziegel aborda a raiz quadrada no seu sexto artigo publicado no Eco. Para tanto, utiliza-se do procedimento da divisão simplificada, apresentando o seguinte problema: 
Houve tempo em que Juca Pituca não possuía uma extensa chácara quadrada. Tratando da compra dum terreno, apresentaram-lhe uma faixa de $1 \mathrm{~km} 323 \mathrm{~m}$ de comprimento por $243 \mathrm{~m}$ de largura (Figura 9). Juca não agradou da oferta. Por que não? Imaginava, quanto tempo desperdiçariam seus empregados, e quanta fadiga lhes sobraria, quando devessem dar uma volta sequer a esse retângulo. Seu perímetro (a cerca ao redor dele) mediria nada menos que $3 \mathrm{~km} 132 \mathrm{~m}$.

Figura 9. Representação dos terrenos do problema

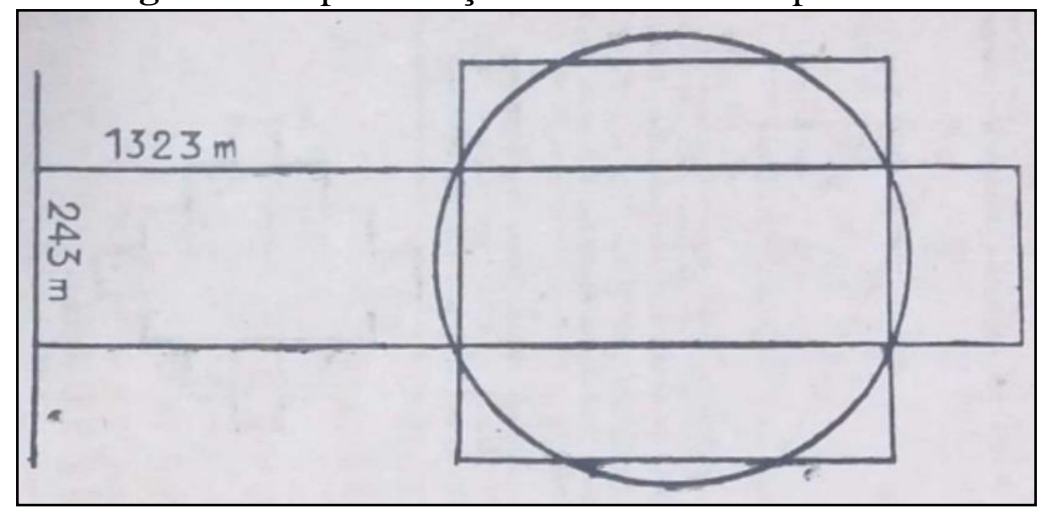

Fonte: O Eco, 1943, v. 6, p. 200.

- Olhe Mané, você não me poderia ceder um círculo da mesma área? Foi sua proposta.

Agora é Mané quem não está pelos autos:

- Se todos me quisessem comprar círculos, quantos vãos não ficariam eu perdendo entre círculo e círculos? Pois uma cerca não se ajustaria à outra. Tocar-se-iam num ponto apenas de cada uma.

Juca sentiu muito... Nem era para menos. A cerca do círculo cobiçado (a periferia) mal chegaria a $2 \mathrm{~km} 10 \mathrm{~m}$ e o diâmetro a $640 \mathrm{~m}$. Enfim, aceitou um último alvitre, e comprou o quadrado que você sabe. Mesmo assim parece que poupou em tempo e fadigas e arame (de cerca) e tudo...

Não são equivalentes (iguais em área) o círculo ambicionado, o quadrado adquirido e o retângulo apresentado (Figura 9)? Qual é, pois essa área? É $1323 \mathrm{~m} \times 243 \mathrm{~m}=321489 \mathrm{~m}^{2}$.

32 ha 14 a $89 m^{2}$ (32 hectares, 14 ares e 89 metros quadrados) é o que você apurou. Agora você está no caso de fazer uma divisão de que conhece o dividendo, e só. Você sabe, entretanto, que divisor e quociente são iguais em valor (equivalentes), por quanto são iguais, em qualquer quadrado, comprimento e largura. Este é, pois o problema: “321489, dividido 
por quanto, dá outro tanto?" Com vantagem você substitui pelo radical a forma de divisão. (O Eco, 1943, v. 6, p. 200).

A partir desse enunciado, o autor propõe determinar as dimensões (comprimento e largura) do terreno quadrado de área $321489 \mathrm{~m}^{2}$, adquirido por Juca Pituca. Essa determinação é realizada através do cálculo da raiz quadrada do número 321489, conforme ilustrado na Figura 10:

Figura 10. Cálculo da raiz quadrada de 321489

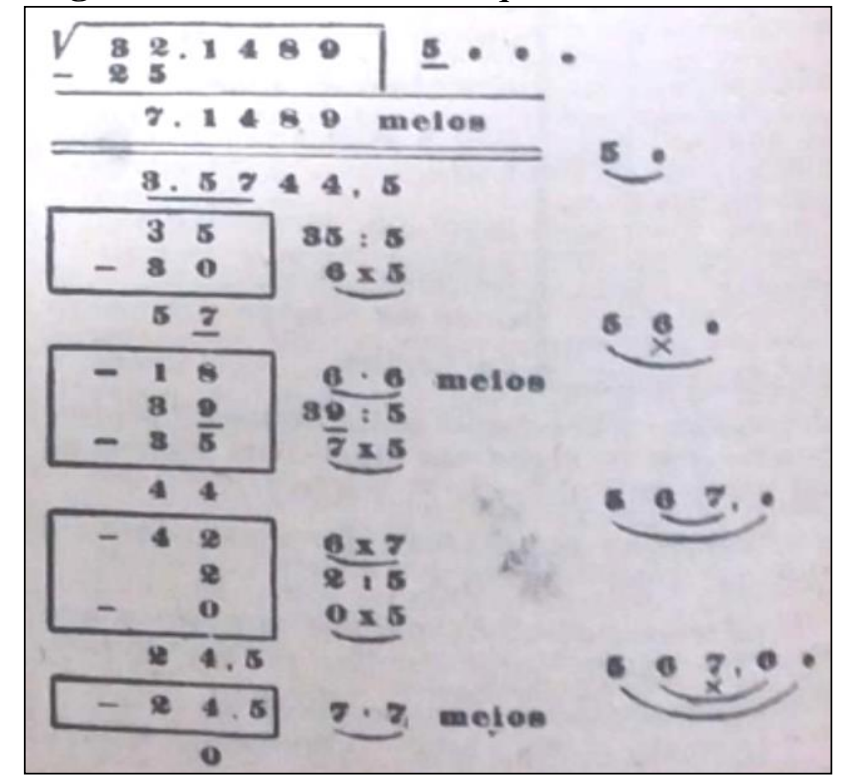

Fonte: O Eco, 1943, v. 6, p. 200.

Nesse cálculo, Reckziegel utiliza alguns passos da divisão simplificada e outras técnicas, para encontrar a raiz quadrada, conforme descrito a seguir:

$1^{\text {a) }}$ Encontrar, por estimativa, o divisor efetivo de 32. Esse número é 5 (primeiro algarismo do quociente), pois $5^{2}=25$ (caso fosse 6 , daria $6^{2}=36$, que não poderia ser subtraído de 32). Logo, $32-25=7$. Então, baixam-se os demais algarismos do radicando e se realiza uma simplificação da raiz quadrada, isto é, dividindo o número 71489 pela metade, encontrando-se 35744,5, que é separado por dois traços do número anterior.

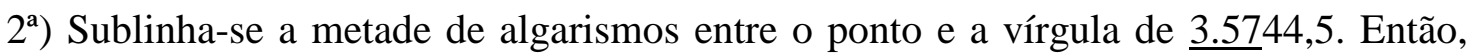
realiza-se processo semelhante à divisão simplificada. Ao dividir 35 por 5 (que é o divisor efetivo), deve-se encontrar, por estimativa, o maior quociente que deixe algum resto e permita a continuidade do cálculo. Nesse caso, seria o 6 que deixa resto 5. Então, baixa-se o 7, para dar andamento à próxima etapa. Como esse 7 é o último algarismo sublinhado no dividendo, deve-se colocar a vírgula após o próximo algarismo do quociente encontrado. 
$3^{\text {a }) ~ E ́ ~ i n i c i a d a ~ c o m ~ a ~ a s s o c i a c ̧ a ̃ o ~ a ̀ ~ r e p r e s e n t a c ̧ a ̃ o ~ d e ~ u m a ~ g u i r l a n d a, ~ o b s e r v a n d o-s e ~ q u e ~ o ~}$ algarismo 5 sustenta o extremo maior, em busca do próximo algarismo do quociente, enquanto o algarismo 6, que está sozinho, recebe uma cruzinha, significando que deve ser multiplicado por ele mesmo, 6 × $6=36$, que é dividido por 2 para completar a simplificação da raiz quadrada $^{15}$, resultando em $36 \div 2=18$, que é subtraído de 57 . Então, a diferença 39 passa a ser dividida por 5. Novamente, é preciso encontrar, por estimativa, o maior quociente que deixe algum resto e permita a continuidade do cálculo. Nesse caso, seria o 7 que deixa resto 4 . Então, baixa-se o 4, para dar andamento à quarta etapa.

$4^{a}$ ) Novamente é feita a associação com a representação de guirlanda, observando que o algarismo 5 sustenta o extremo maior em busca do próximo algarismo do quociente, enquanto o algarismo 6 é ligado ao algarismo 7 do quociente, originando-se o produto $6 \times 7=$ 42, que é subtraído de 44. Logo, a diferença 2 passa a ser dividida por 5. Novamente, é preciso encontrar, por estimativa, o maior quociente que deixe algum resto e permita a continuidade do cálculo. Encontra-se o 0, que deixa resto 2, e se coloca após a vírgula no quociente. Em seguida, baixa-se o 4,5, restante do dividendo, pois o 4 é o último algarismo antes da vírgula, para dar andamento à última etapa do cálculo.

$5^{\text {a) }}$ Ao fazer a associação com a representação de guirlanda, o algarismo 5 continua sustentando o extremo maior em busca do próximo algarismo do quociente, enquanto o algarismo 6 é ligado ao algarismo 0 do quociente $(6 \times 0=0)$ e o algarismo 7 que está sozinho, recebe uma cruzinha, significando que deve ser multiplicado por ele mesmo, 7 x $7=49$, que é dividido por 2 para completar a simplificação da raiz quadrada, resultando em $49 \div 2=24,5$, que é somado com 0 e subtraído de 24,5, encontrando-se a diferença 0. Então, chega-se ao final do cálculo, concluindo-se que $\sqrt{321489}=567$.

Portanto, as dimensões do terreno quadrado adquirido por Juca Pituca são 567 m x 567 m, cuja área é $321489 \mathrm{~m}^{2}$. Ressalta-se que o tema desse artigo de Reckziegel, a dupla simplificação da raiz quadrada, justifica-se pela tomada das metades (meios) de números em três momentos do cálculo, conforme destacado na Figura 10.

No sétimo artigo, Reckziegel apresenta outro enunciado envolvendo Juca Pituca:

\footnotetext{
${ }^{15}$ Esse procedimento é realizado toda vez que um algarismo do quociente fica sem ligação, ou seja, está sem par para fazer a multiplicação.
} 
Depois de prolongada e calamitosa estiagem, Juca Pituca mandou construir na Vila Chica, colossal cisterna de 432 dm de comprimento interno, por 324 dm de largura e $243 \mathrm{dm}$ de fundura (profundidade). Com a provisão desses 34012224 litros d'água espera poder saciar, em tempo de carestia, sua gente, seus gados e máquinas, suas pastagens, sementeiras e plantações, seus peixes, aves e abelhas, seu parque e bosque, pomar e jardim... Sua chácara mista sempre progredirá: - eis a parte material das suas esperanças. (O Eco, 1943, v. 7, p. 228).

O problema proposto pelo autor se resume em determinar $\sqrt[3]{34012224}$. Antes, porém, de iniciar o cálculo dessa raiz cúbica, apresenta alguns termos que utiliza no procedimento de extração dessa raiz: "cometa", "estrela" e "guirlanda dupla", conforme as representações ilustradas na Figura 11:

Figura 11. Representação de elementos empregados no cálculo da raiz cúbica

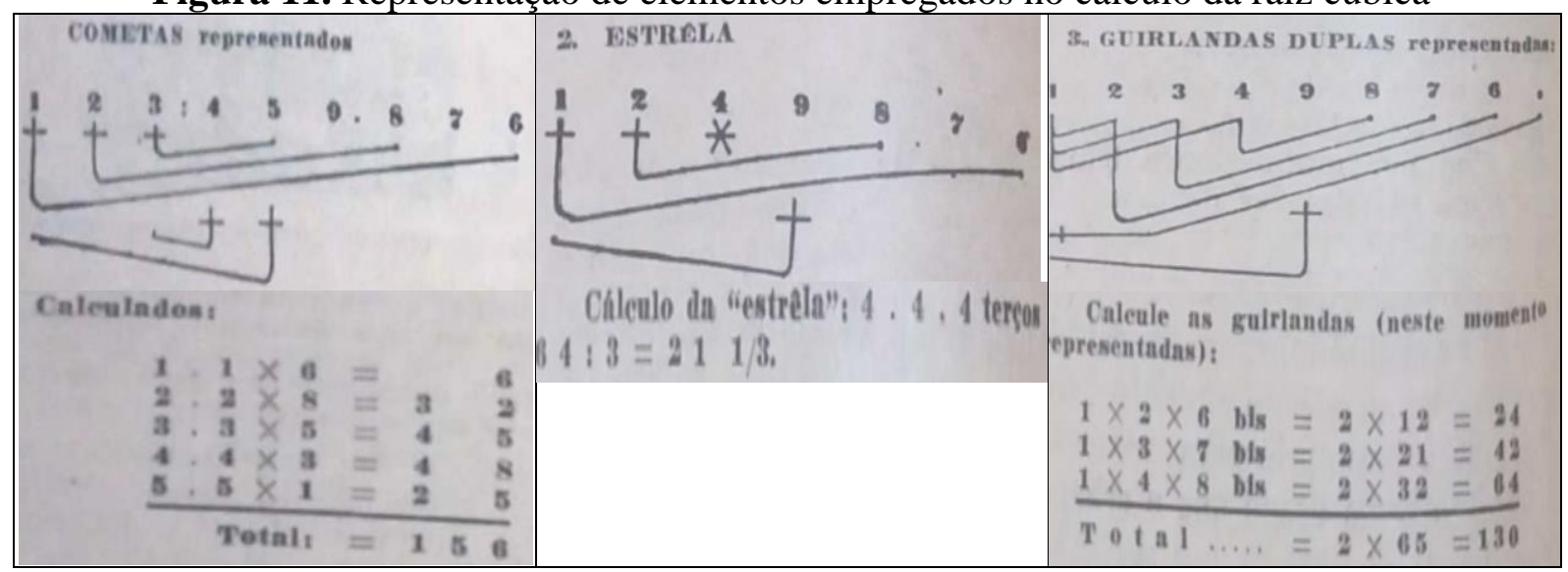

Fonte: O Eco, 1943, v. 7, p. 228.

$\mathrm{Na}$ derivação dos cometas representados na Figura 11 é preciso considerar os movimentos em separado: primeiro, da cabeça do cometa e, segundo, da cauda. Quando a cabeça avança uma casa (de 1 até 5), a cauda recua duas casas $(6,8,5,3,1)$, respectivamente.

Conforme a Figura 11, a representação da estrela é por baixo do 4. A simplificação específica da raiz cúbica exige que toda estrela seja dividida por 3. Exime-se desta regra somente o primeiro astro sob os pés do divisor efetivo (1), pois ainda não começou a simplificação específica. A estrela se deriva automaticamente de um cometa, cuja cauda e cabeça se encontram para ocupar o mesmo posto.

As guirlandas duplas são sempre bisadas, isto é, multiplicadas por 2. As guirlandas se derivam do cometa maior, conforme ilustrado na Figura 11: a cabeça desse cometa se dissolve, 
mantendo-se fixo no divisor efetivo um ponto dela (um gancho) e avançando o segundo ponto (passo por passo, para a direita); a cauda, desde a casa vazia, começa a recuar, no mesmo passo (para a esquerda).

Feitas essas considerações, o autor realiza o cálculo da $\sqrt[3]{34012224 \mathrm{dm}^{3}}$, pelo método duplamente simplificado, conforme mostrado na Figura 12:

Figura 12. Cálculo da raiz cúbica de 34012224

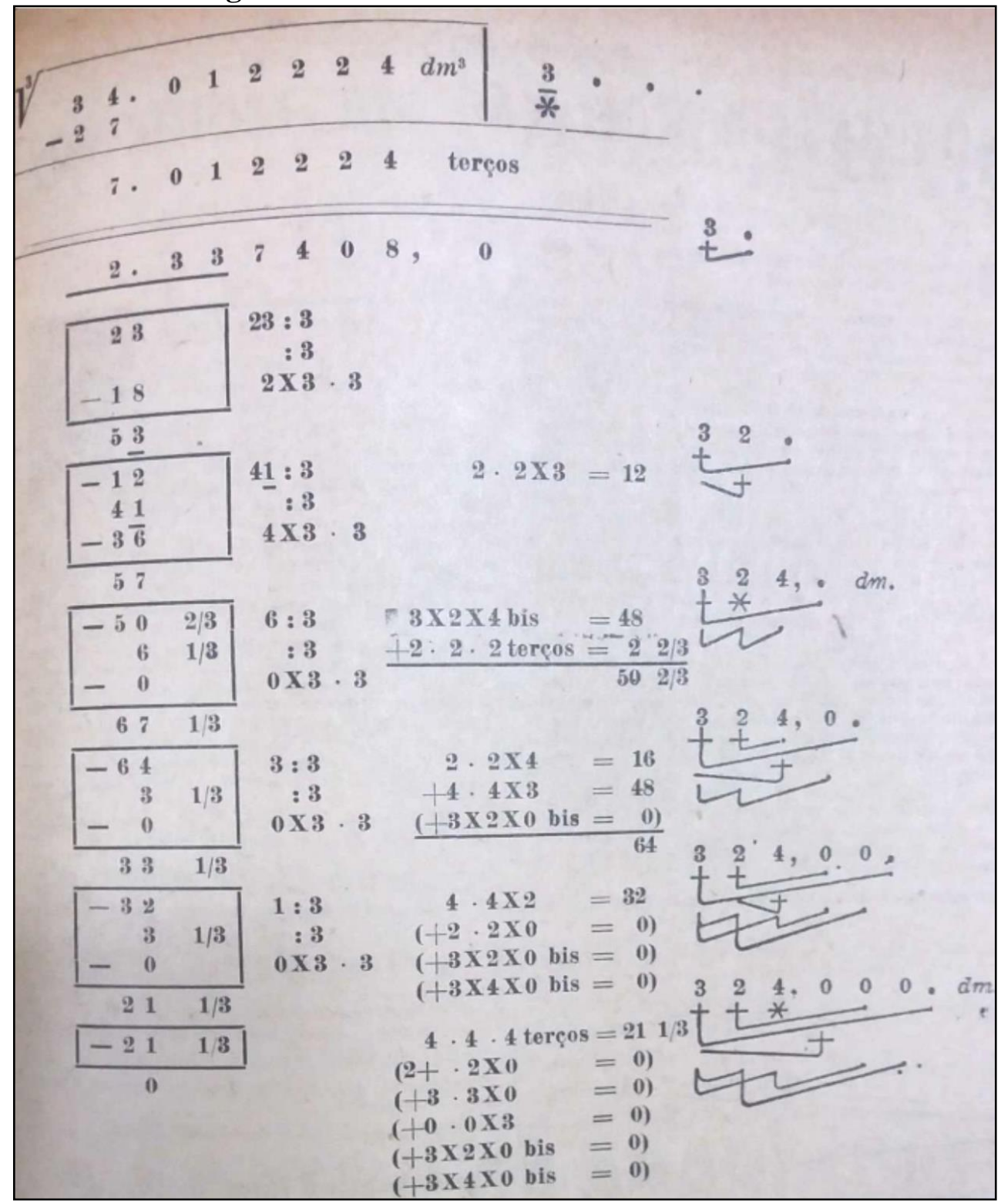

Fonte: O Eco, 1943, v. 7, p. 229.

Com relação a esse cálculo, Reckziegel faz algumas observações (O Eco, 1943, v. 7): 
1) As secções do radicando, como na extração da raiz quadrada são de duas, na extração da raiz cúbica, são de três casas. Dos talhos, o primeiro dá-se sempre a vírgula.

2) A primeira secção (grupo de um a três algarismos) fornece o divisor efetivo, conforme a lista abaixo, formada por duas linhas paralelas, que contêm, a primeira os cubos dos números contidos na segunda:

$$
\begin{array}{cccccccccl}
1 & 8 & 27 & 64 & 125 & 216 & 343 & 512 & 729 & \\
1 & 2 & 3 & 4 & 5 & 6 & 7 & 8 & 9 & \text { Divisor efetivo }
\end{array}
$$

3) Obtido o divisor efetivo, e isolado, por linha dupla, o resto total, da sua terça parte, como na raiz quadrada duplamente simplificada, sublinha-se não a metade, mas a primeira terça parte das casas entre o ponto e a vírgula $(\underline{2.337408,0)}$.

4) A estimativa é uma divisão, com folga para o resto; mas, na raiz cúbica, divisão repetida. Na Figura 12, por exemplo, 23 dividido por 3, dá 7; 7 dividido por 3, dá 2, que é o segundo algarismo procurado do resultado.

5) O cometa maior, em todos os momentos, representa o papel saliente que a raiz quadrada reservou para a maior guirlanda. O cometa maior é o primeiro a ser marcado (com a cabeça no divisor efetivo e na casa desconhecida, a cauda). Do cometa maior se derivam, diretamente, tanto as guirlandas duplas como os cometas menores, e ainda as estrelas. O cometa maior é o último a ser calculado, em cada momento, que guia para a cabeceira dos cartões (de subtração) a parte conhecida do subtraendo, e para os pés deles, (parte inferior dos cartões), a que, antes da estimativa, é desconhecida (o cometa maior).

6) A estrela (que ocorre a cada terceiro momento) deixa, de fração, ora nada (0), ora um terço (1/3), ora dois terços (2/3). Então, baixa-se só uma casa do "terço do resto" (terça parte do resto, resto dividido por 3), também por cima do cartão encabeçado por subtraendo com parte fracionária, como o terceiro cartão do exemplo na Figura 12. Daí por diante, ficará, de "resto", entre os cartões seguintes: "tanto e fração". Então, intercala-se entre "tanto" (que passa a formar dezenas) e a "fração" a soma seguinte: o algarismo a ser descido, mais 6 (quando a fração é 2/3); mais 3 (quando é 1/3). Com isto pode dar-se, que as dezenas mudem para "tanto, mais um", como no exemplo da Figura 12, por cima do último cartão.

Resta 1 1/3 ou 1,33 e baixa-se 8

Escreve-se $131 / 3$ ou 13,3 


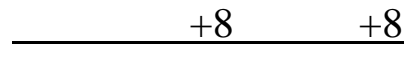

\section{Ao todo $211 / 3$ ou 21,3}

Se o algarismo a baixar é o das unidades, e seguido de fração, baixa-se logo também a fração. Além da soma já indicada para as unidades (algarismo baixado, mais 6 ou 3, respectivamente), entre os cartões somam-se também duas frações (caso já venha restado fração), pelo que pode ocorrer que a soma das unidades cresça de um.

Assim, ao calcular a $\sqrt[3]{34012224 \mathrm{dm}^{3}}$ pelo método duplamente simplificado, conforme descrito na Figura 12, encontra-se 324 dm. Então, as dimensões de uma cisterna cúbica com $34012224 \mathrm{dm}^{3}$ seriam $324 \mathrm{dm}$ de comprimento, por $324 \mathrm{dm}$ de largura e $324 \mathrm{dm}$ de profundidade.

Nesse artigo, Reckziegel também faz referência à média geométrica ${ }^{16}$, para a determinação das dimensões do terreno quadrado de Juca Pituca, abordado no artigo anterior. A partir do cálculo da média geométrica de 243 m e 1323 m, dimensões do terreno retangular, encontra-se a medida dos lados do terreno quadrado, ou seja, $567 \mathrm{~m}$, pois $\sqrt{243 \cdot 1323}=\sqrt{321489}=567$. Da mesma forma, considerando as dimensões da cisterna construída por Juca Pituca, determinar $\sqrt[3]{34012224}$ equivale a calcular a média geométrica de $243 \mathrm{dm}, 324 \mathrm{dm}$ e $432 \mathrm{dm}$, que é $324 \mathrm{dm}$, pois $\sqrt[3]{243 \cdot 324 \cdot 432}=\sqrt[3]{34012224}=324$.

No artigo "Somar pelos dedos", o autor afirma que na adição, começa a somar unidades com unidades $\left(1^{\mathrm{a}}\right.$ ordem $)$, continua a somar com a reserva das unidades, dezenas e dezenas ( $2^{\mathrm{a}}$ ordem) e assim, por diante, até ter somado todas as ordens. Mas o diferencial está na forma como ele adiciona os algarismos em cada ordem, utilizando-se dos 5 dedos de cada mão, totalizando 10. Para tanto, propõe reduzir todas as somas, ordem por ordem, de 5 mais 5 , e mais alguma coisa. Para o autor, cada algarismo maior que 5, começa a valer, 5 mais tanto. Por exemplo: $6=5+1$ e $7=5+2$. O 5 representa uma mão, da outra contava 1 dedo para 6 ; com 2 dedos contava 7, com 3 dedos chegava em 8 e com 4 dedos contava 9 .

$\mathrm{Na}$ adição $7+8$, por exemplo, propõe: $7+8=(5+2)+(5+3)=10+5=15$. De acordo com o autor, seria $5+5$ e mais alguma coisa. Trata-se da reserva e dois algarismos menores que 5 . Considera 1 (o polegar) +4 , numa mão, e noutra, 2 (polegar e indicador) +3 .

\footnotetext{
${ }^{16}$ A média geométrica dos números $a_{1}, a_{2}, a_{3}, \ldots, a_{n}$ é dada por $G=\sqrt[n]{a_{1} \cdot a_{2} \cdot a_{3} \cdot \ldots \cdot a_{n}}$.
} 
São esses dois pares de parcelas os únicos que completam exatamente 5. Os demais, não completam e são uma soma simples: $1+1 ; 2+1 ; 2+2 ; 3+1$.

O penúltimo artigo de Reckziegel, intitulado "Máquina de Chiquinho", compara os dedos das mãos com uma máquina e aborda, novamente, a operação de multiplicação. O autor indica que os polegares representam o 6, os indicadores o 7, os médios o 8, os anelares o 9 e os minguinhos representam o 10. Então, explica como multiplicar 7 x 8, usando essa “máquina”. Para isso, deve-se unir os dedos multiplicandos, 7 de uma das mãos (indicador) com 8 da outra (dedo médio). Contam-se os dedos estendidos, que são 5 e vão representar 50. Então, separadamente, contam-se os dedos fechados em cada mão e se realiza a multiplicação desses, ou seja, 3 × $2=6$. Logo, o produto será $50+6=56$.

No caso da multiplicação 6 x 7, deve-se unir o 6 de uma das mãos (dedo polegar) com 7 da outra (indicador). Contam-se os dedos estendidos, que são 3 e vão representar 30. Então, separadamente, contam-se os dedos fechados em cada mão e se realiza a multiplicação desses, ou seja, 4 x $3=12$. Logo, o produto será $30+12=42$. O autor ressalta que essa forma de realizar multiplicações também é encontrada no livro Cálculo mental ultra-rápido (s.d.), de autoria de José Clotet ${ }^{17}$.

Essa máquina também pode ser usada na divisão, quando se estima um quociente e sabe-se que ele é maior do que 5. Nesse caso, estendem-se os dedos e conta-se até o divisor efetivo os dedos de uma das mãos e fecham-se os outros. Então, abrem-se os dedos da outra mão, a partir do polegar, até completar o valor do algarismo das dezenas (do dividendo do momento). O último dedo que se abre (o que completa aquelas dezenas) é da marca "mais tanto" ("5 mais tanto" é o quociente procurado). Seja, por exemplo, $60 \div 8$ a divisão a fazer. Estendem-se os dedos, numa das mãos, até o divisor efetivo 8 (dedo médio) e se contam os dedos estendidos até 3. Como as dezenas de 60 são 6, continua-se a contagem na outra mão, começando pelo polegar. Então, realiza-se a multiplicação dos dedos fechados, ou seja, 2 × 2 = 4. Porém, $60+4=64$, que é maior que o dividendo 60. Logo, 6 é demais. Então, fecha-se o

\footnotetext{
17 O livro possui 178 páginas, apresenta prefácio do próprio autor e capítulo sobre soma, subtração, multiplicação, multiplicação abreviada, fundamento da multiplicação abreviada, fundamento da multiplicação abreviada para três cifras, divisão, potenciação, raízes, coeficientes binomiais, problemas, xadrez, curiosidades, calendário gregoriano, outros calendários, gracejo matemático e curiosidades e finaliza como uma advertência sobre como fazer uso das multiplicações abreviadas. O livro possui ainda imagens do General José Antônio Flores da Cunha, para quem é dedicado o livro, e do autor José Clotet, opiniões dos jornais de Porto Alegre, um soneto do autor e errata. José Clotet era um engenheiro espanhol, conhecido mundialmente como "um verdadeiro assombro em cálculos”, pela sua memória ao resolver cálculos aritméticos (Clotet, S.d., p. 169).
} 
último dedo aberto, unindo-se o dedo médio da primeira mão com o indicador da outra, encontrando-se o quociente 7 (5 mais o tanto 2). Os dedos estendidos são 5, equivalendo a 50; os dedos fechados são $2 \times 3=6 ; 50+6=56$ e $60-56=4$. Portanto, $60 \div 8=7$ mais o resto 4 $(7 \times 8+4=56+4=60)$.

No seu último artigo, Reckziegel explica porque a "máquina do Chiquinho" funciona. Calcular 7 x 8 seria o mesmo que multiplicar (10 menos 3) por (10 menos 2); 3 e 2 são chamados de complementos de 7 e 8, porque completam alguma potência de 10, base do sistema decimal. Considerando "negativos" os valores "menos 3" e "menos 2", os fatores que se tem são 10 com alguma falta: 10 com a falta de 3 é o multiplicando 7; e o multiplicador 8 é 10 com a falta de 2. Ao multiplicar entre si dois valores negativos, obtém-se um produto positivo: $(-2)$ x $(-3)=+6$. Porque multiplicar é uma ação. E, por exemplo, dar: dar umas tantas vezes o multiplicando caso o multiplicador seja positivo; caso for negativo o multiplicador, será tirar: tirar umas tantas vezes o multiplicando. O que se tira é a falta de alguma coisa, o que realmente se faz é dar aquela mesma coisa: tirar duas vezes a falta de três significa dar duas vezes três. (O Eco, 1943, v. 11).

Aplicando-se no produto 7 x 8 a ideia das guirlandas (O Eco, 1943, v. 3), tem-se: $(10-3) \times(10-2)=100-(3+2) \times 10+6$.

Esse 6 é o produto dos complementos (dedos fechados, 3 × $2=6$ ) e dão as unidades do resultado. A outra parte do resultado, $100-(3+2)$ x 10 unidades, são as dezenas, 10 menos a soma dos complementos $(3+2)$, ou seja, os 5 dedos estendidos na máquina de Chiquinho. De acordo com Reckziegel, a mesma máquina pode ser usada na estimativa do quociente numa divisão, pois essa operação é o inverso da multiplicação (O Eco, 1943, v. 11).

Como o uso desta "máquina" poderia significar pouco domínio da tabuada, o autor apresenta um exemplo com números maiores, 999931 x 7996, conforme a Figura 13:

Figura 13. Multiplicação de 999931 x 7996 com a máquina de Chiquinho

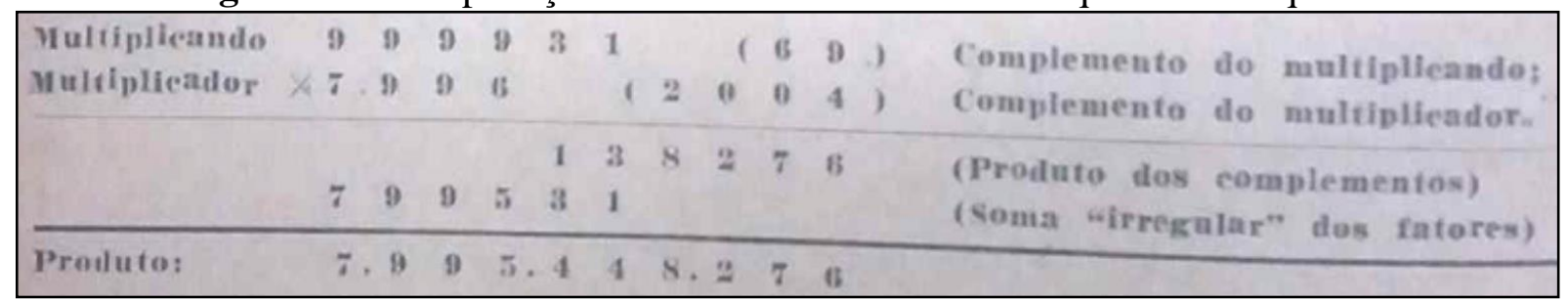

Fonte: O Eco, 1943, v. 11, p. 380. 
Para facilitar a compreensão da multiplicação de 999931 por 7996, o autor escreve, separadamente, em duas linhas, os complementos entre parênteses (complementos do multiplicando e do multiplicador), o produto dos complementos (produto da direita) e a "soma irregular" dos fatores (soma da esquerda). Para, então, chegar ao produto 7995448276.

Observa-se que a soma tem duas irregularidades: Juntam-se, nas mesmas ordens, não as unidades à direita (conforme a regra geral da adição), mas as primeiras casas da esquerda (cada fator foi multiplicado pela potência de 10 que o outro quase integra). No exemplo acima, ter-se-ia somado assim a última ordem (isto é, a primeira ordem à esquerda): 9 mais 7 e mais a reserva 1 são 17. Essa é a segunda irregularidade: deixa-se 7 (na casa dos bilhões) e risca-se 1 (a máquina do Chiquinho permite essa possibilidade de errar, pois tem só duas mãos) (O Eco, 1943, v. 11).

Além disso, o produto dos dois complementos (dos dedos fechados) ocupa, à direita, tantas casas do resultado, quantas tem o menor dos fatores (o multiplicador). Portanto, esse produto poderá seguir a série dos algarismos da soma irregular, aos zeros intercalados, ou se engatará, como no exemplo acima, no fim da soma irregular (O Eco, 1943, v. 11).

Esse foi o último artigo assinado pelo jesuíta Luiz Monteiro Reckziegel e encontrado no periódico O Eco. Não se tem conhecimento sobre a participação desse autor na proposição de perguntas, problemas e curiosidades, envolvendo Matemática, localizados em outras edições do periódico, especialmente, nas seções recreativas. Todavia, o personagem "Chiquinho" é citado em problemas propostos na seção "Para Pequenos Mathemáticos", que se fez presente em 31 edições do periódico O Echo, nos anos de 1919, 1920, 1921 e 1924.

\section{Considerações finais}

A partir do referencial da pesquisa histórica, investigou-se o periódico ilustrado O Eco, com atenção especial para os dez artigos sobre Matemática, escritos pelo jesuíta Luiz Monteiro Reckziegel, em 1943. O público-alvo do periódico era a comunidade escolar e a mocidade católica brasileira, pois, segundo os editores, havia periódicos para os diferentes públicos na época, exceto para os jovens estudantes. A intencionalidade dos editores consistia em inserir algo que contemplasse todas as vozes, do sábio, narrador, colega jovial, historiador, jornalista, religioso, tudo isso para a vida da mocidade estudiosa, por meio de textos, histórias, 
informações e curiosidades, enfatizando os aspectos morais, religiosos (religião católica) e a formação em geral.

Os artigos escritos no periódico O Eco trazem poemas, notícias, reflexões de padres e professores, conferências, variedades, anedotas, contos, publicações de premiações de alunos por redação ou por competição esportiva, anúncios de propagandas, Ciências, invenções, Artes, Astronomia, Matemática, reforma da Língua Portuguesa, descobertas, sendo que, após 1950, começam a aparecer artigos direcionados à prática esportiva, como futebol, bola ao cesto, entre outros. Nessas publicações, também há ilustrações, como fotografias de colégios, imagens de religiosos, alunos, ex-alunos, personagens da história do Brasil, santos da Igreja Católica, paisagens, ilustrações de textos, cenários de guerra, futebol e humor, traduzindo práticas culturais da época.

Desde as primeiras publicações do periódico, em 1914, até o encerramento de suas atividades, no final da década de 1960, a Matemática se fazia presente através de seções recreativas, tais como charadas, enigmas, perguntas, problemas e curiosidades, englobando conhecimentos aritméticos, algébricos e geométricos, valorizando o pensamento lógicomatemático dos leitores com desafios, premiando assinantes com as soluções corretas.

No ano de 1943, de modo particular, além das seções recreativas, identificou-se, em dez edições do periódico $\mathrm{O}$ Eco, artigos específicos sobre Matemática, abordando procedimentos de cálculo elementares, objetivando facilitar a obtenção de seu resultado. Esses artigos são assinados por Luiz Monteiro Reckziegel, formado em Filosofia e Teologia, com atuação, predominante, no ensino de Ciências Exatas. Tais artigos sobre Matemática abordam procedimentos de cálculo escrito e mental envolvendo as operações aritméticas de adição, multiplicação, divisão e radiciação (raiz quadrada e raiz cúbica), com destaque para a operação de multiplicação, tema de seis artigos. Registra-se, também, a ênfase, dada pelo autor, às estimativas nos procedimentos de cálculo apresentados. Na época, era fundamental saber resolver cálculos aritméticos, tanto escritos, quanto mentais, de forma precisa e rápida, nas mais diversas situações do dia a dia.

Ao abordar cada operação aritmética, o autor buscou fazer associações com elementos do universo do público leitor, como movimentos de trem e de janelas, guirlandas, cometas e estrelas. Além disso, procurou fazer contextualizações com áreas de superfícies (terrenos) e volume de corpos (cisterna), explorando suas unidades de medidas. Com esses artigos, o autor 
buscava despertar o interesse e a curiosidade da mocidade estudiosa, contribuindo para a circulação do periódico e a formação da juventude católica nos colégios onde $\mathrm{O}$ Eco circulava.

O estudo da Matemática presente nos artigos escritos pelo jesuíta Reckziegel, permitiu um adentramento numa cultura escolar, num lugar e num tempo determinados, contribuindo, assim, para a História da Educação Matemática e o ensino de Matemática na Educação Básica, pois os procedimentos de cálculo apresentados podem servir de estímulo para reflexão sobre os métodos empregados nas escolas atualmente.

\section{Referências}

Britto, S. L. M. (2016). O ensino da aritmética nas escolas paroquiais católicas e no Ginásio Conceição, sob a ótica dos jesuítas nos séculos XIX e XX (Tese de Doutoramento). Universidade Luterana do Brasil, Canoas.

Britto, S. L. M., Bayer, A., \& Kuhn, M. C. (2020). A contribuição dos jesuítas para o ensino da Matemática no Rio Grande do Sul. São Leopoldo, RS: Ed. UNISINOS.

Cellard, A. (2008). A análise documental. In Poupart, J. et al., A pesquisa qualitativa: enfoques epistemológicos e metodológicos (pp. 291-298). Petrópolis/RJ: Vozes.

Certeau, M. (1982). A escrita da História. Rio de Janeiro: Forense Universitária.

Clotet, J. (S.d.). Cálculo mental ultra-rápido. Coleção Curiosidades Matemáticas (36ª ed.). Porto Alegre: Livraria do Globo.

Colégio Anchieta: cem anos. (1990). Porto Alegre.

O Echo: revista ilustrada para a mocidade estudiosa. (1914-1931). Typographia do Centro: Porto Alegre.

O Eco: revista ilustrada para a mocidade brasileira. (1932-1969). Tipografia do Centro: Porto Alegre.

Kreutz, L. (1991). O professor paroquial: magistério e imigração alemã. Porto Alegre: Ed. da UFRGS; Caxias do Sul: EDUCS.

Kreutz, L. (1994). Material didático e currículo na escola teuto-brasileira. São Leopoldo: Ed. UNISINOS.

Kuhn, M. C. (2015). O ensino da matemática nas escolas evangélicas luteranas do Rio Grande do Sul durante a primeira metade do século XX (Tese de Doutoramento). Universidade Luterana do Brasil, Canoas.

Kuhn, M. C., \& Bayer, A. (2017a). A matemática nas escolas paroquiais luteranas gaúchas do século XX. Canoas: Ed. ULBRA.

Kuhn, M. C., \& Bayer, A. (2017b). O contexto histórico das escolas paroquiais luteranas gaúchas do século XX. Canoas: Ed. ULBRA.

Leite, L. O. (2005). Jesuítas cientistas no sul do Brasil. São Leopoldo: UNISINOS. 
Leite, L. O. (2018, 16 de março). A revista O Eco e sua trajetória. Entrevista para Estágio Pós-doutoral em Programa de Pós-Graduação. Porto Alegre/RS.

Leite, L. O. (2019, 25 de janeiro). Biografia do jesuíta Luiz Monteiro Reckziegel. Entrevista para Estágio Pós-doutoral em Programa de Pós-Graduação. Porto Alegre/RS.

Mauro, S. (2005). Uma história da matemática escolar desenvolvida por comunidades de origem alemã no Rio Grande do Sul no final do século XIX e início do século XX (Tese de Doutoramento). Universidade Estadual Paulista, Rio Claro.

Mello \& Souza. (1939). Histórias e Fantasias da Matemática (1ª ed.). Rio de Janeiro: Getulio M. Costa.

Prost, A. (2008). Doze lições sobre a História. Belo Horizonte: Autêntica.

Rambo, A. B. (1994). A escola comunitária teuto-brasileira católica. São Leopoldo: Ed. UNISINOS.

Rambo, A. B. (1996). A escola comunitária teuto-brasileira católica: a associação de professores e a escola normal. São Leopoldo: Ed. UNISINOS.

Relatório do Colégio Anchieta. (1914). Porto Alegre.

Serra, A. E. (2010). As associações de alunos das escolas normais do Brasil e de Portugal: apropriação e representação (1906-1927) (Tese de Doutoramento). Universidade Estadual Paulista, Marília.

Valente, W. R. (2007). História da Educação Matemática: interrogações metodológicas. REVEMAT - Revista Eletrônica de Educação Matemática, 2.2, pp. 28-49.

Wanderer, F. (2007). Escola e Matemática Escolar: mecanismos de regulação sobre sujeitos escolares de uma localidade rural de colonização alemã no Rio Grande do Sul (Tese de Doutoramento). Universidade do Vale do Rio dos Sinos, São Leopoldo.

Weiduschadt, P. (2007). O Sínodo de Missouri e a educação pomerana em Pelotas e São Lourenço do Sul nas primeiras décadas do século XX: identidade e cultura escolar (Dissertação de Mestrado). Universidade Federal de Pelotas, Pelotas.

Weiduschadt, P. (2012). A revista “O Pequeno Luterano” e a formação educativa religiosa luterana no contexto pomerano em Pelotas - RS (1931-1966) (Tese de Doutoramento). Universidade do Vale do Rio dos Sinos, São Leopoldo.

Autores:

Silvio Luiz Martins Britto. Doutor em Ensino de Ciências e Matemática pela Universidade

Luterana do Brasil - ULBRA/Canoas/RS. Estágio Pós-doutoral no Programa de PósGraduação em Ensino de Ciências e Matemática - PPGECIM - da Universidade Luterana do

Brasil - ULBRA/Canoas/RS. Professor das Faculdades Integradas de Taquara FACCAT/Taquara/RS. Membro do Grupo de Pesquisas sobre Formação de Professores de Matemática - GPFPMat.

Malcus Cassiano Kuhn. Doutor em Ensino de Ciências e Matemática pela Universidade Luterana do Brasil - ULBRA/Canoas/RS. Estágio Pós-doutoral no Programa de PósGraduação em Ensino de Ciências e Matemática - PPGECIM, na Universidade Luterana do Brasil - ULBRA/Canoas/RS. Professor do Ensino Básico, Técnico e Tecnológico no Instituto 
Federal de Educação, Ciência e Tecnologia Sul-rio-grandense - IFSul Câmpus Lajeado/RS. Chefe do Departamento de Ensino, Pesquisa e Extensão do Instituto Federal de Educação, Ciência e Tecnologia Sul-rio-grandense - IFSul Câmpus Lajeado/RS. Coordenador do Polo UAB do IFSul Câmpus Lajeado/RS. Membro da Câmara de Ensino do IFSul. Membro titular da Câmara de Pesquisa, Inovação e Pós-graduação do IFSul, representando a grande área de Ciências Exatas e da Terra. Membro titular do Conselho Editorial da Editora IFSul. Membro do Grupo de Pesquisas sobre Formação de Professores de Matemática - GPFPMat. Líder do Grupo de Pesquisa Estratégias de Ensino para Educação Básica e Profissional.

Arno Bayer. Doutor em Ciências da Educação pela Universidade Pontifícia de Salamanca Espanha. Professor e Pesquisador do Programa de Pós-Graduação em Ensino de Ciências e Matemática - PPGECIM da ULBRA/Canoas/RS. Líder do Grupo de Pesquisas sobre Formação de Professores de Matemática - GPFPMat. 